\title{
Morphological and allozyme variation in a collection of Cucumeropsis mannii Naudin (Cucurbitaceae) from Côte d'Ivoire
}

\author{
Kouamé K. Koffi ${ }^{\mathrm{a}}$, Ahou A. Gbotto ${ }^{\mathrm{a}}$, Marie Malice ${ }^{\mathrm{b}}$, Yao Djè ${ }^{\mathrm{a}}$, Pierre Bertin ${ }^{\mathrm{c}}$, \\ Jean-Pierre Baudoin ${ }^{\mathrm{b}}$, Irié $\mathrm{A}$. Zoro $\mathrm{Bi}^{\mathrm{a}, *}$ \\ a Université d'Abobo-Adjamé, UFR des Sciences de la Nature 02, BP 801 Abidjan 02, Côte d'Ivoire \\ ${ }^{\mathrm{b}}$ Unité de Phytotechnie Tropicale et d'Horticulture, Faculté universitaire des Sciences agronomiques de Gembloux, Passage des Déportés 2 , \\ B-5030 Gembloux, Belgium \\ ${ }^{\mathrm{C}}$ Unité d'Ecophysiologie et Amélioration Végétale, Université catholique de Louvain, Belgium
}

\section{A R T I C L E I N F O}

\section{Article history:}

Received 25 February 2008

Accepted 26 July 2008

\section{Keywords:}

Isozyme variation

Cucumeropsis mannii

Cucurbit

Morphological variability

Cultivar identification

\begin{abstract}
A B S T R A C T
To set up a rational collecting strategy for germplasm of the edible-seeded cucurbit Cucumeropsis mannii, a study was conducted using 24 morphological and seven putative enzyme markers to determine the intra-specific variability from 16 and 22 accessions (representing three cultivars), respectively. The analysis of variance, showed a significant difference between the three cultivars. Principal component analysis pointed out a variation among individuals, mainly on the basis of flower, fruit, and seed size. Dendrogram with UPGMA method allowed clustering of the cultivars. Genetic diversity indices estimated equalled: $9.96 \%$ for the proportion of polymorphic loci $(P), 1.10$ for the number of alleles $(A)$ and 0.023 for observed heterozygosity $\left(H_{0}\right)$. The level of the within accessions genetic diversity $\left(H_{\mathrm{S}}=0.078\right)$ was higher than among accessions $\left(D_{\mathrm{ST}}=0.042\right)$. Nei's genetic distances between the three cultivars were also low (0.079-0.147), indicating a high degree of similarity of the analysed cultivars.
\end{abstract}

Crown Copyright $\odot 2008$ Published by Elsevier Ltd. All rights reserved.

\section{Introduction}

Plant genetic resources, used for various purposes (agronomy, industry, environment, ecology, medicine, etc.), and thus possessing an important economic and social value are essential for humanity survival. To satisfy the future needs in genetic resources, it is imperative to collect and conserve representative stocks of plant genetic diversity (Given, 1987). Indeed, the chance for fulfilling future demand of genetic resources is better when a high level of genetic diversity is conserved and made available for breeders. This challenge should not be missed, particularly for the crops such as neglected and underutilised by both national and international research programs, so called minor or orphan crops (Rasul et al., 2007). The indigenous edible-seeded cucurbits are classified into the minor crops. There are several species of cucurbit in tropical Africa and Asia, cultivated mainly for their oleaginous seeds that are important in the social and cultural life of several peoples (Badifu, 1993; Das et al., 2002; Enujiugha and Ayodele-Oni, 2003; Achu et al., 2005; Zoro Bi et al., 2005). Cucumeropsis mannii Naudin belonging to this category of crop, is one of the most widely distributed and consumed at both rural and urban levels in Sub-Saharan Africa. A preliminary agronomic evaluation

\footnotetext{
* Corresponding author. Tel.: +225073902 31; fax: +225 20304256.

E-mail addresses: koffikevin@yahoo.fr (K.K. Koffi), aniquegbotto@yahoo.fr (A.A. Gbotto), malice.m@fsagx.ac.be (M. Malice), saticlan@yahoo.fr (Y. Djè), pierre.bertin@uclouvain.be (P. Bertin), baudoin.jp@fsagx.ac.be (J.-P. Baudoin), zorobi@uabobo.ci (I.A. Zoro Bi).
} 
based on seed traits (size, 100-seeds weight, seed number per fruit, and germination rate) highlighted the occurrence of three cultivars of $C$. mannii in Côte d'Ivoire (Zoro Bi et al., 2003, 2006). This species is an annual climbing vine, able to climb up to 3-5 m. According to peasants, maximizing yield of this species implies vertically training of vines. For this reason, $C$. mannii is usually intercropped with yam, since the latter also needs training trellis to yield (Zoro Bi et al., 2005). In Sub-Saharan Africa, C. mannii is prized for its oleaginous seeds consumed as thickeners of a traditional soup called egussi soup in Cameroon, Nigeria or Benin and pistachio soup in Côte d'Ivoire (Enujiugha and Ayodele-Oni, 2003; Achu et al., 2005; Zoro Bi et al., 2005; Loukou et al., 2007). This cucurbit is reported to be rich in nutrients (Badifu, 1993; Enujiugha and Ayodele-Oni, 2003; Achu et al., 2005), namely protein (36 $\pm 2.17 \%)$ and fat (45.89 $\pm 4.73 \%$ ). In addition, commonly found in many traditional cropping systems, the plant is well adapted to extremely divergent agroecosystems and various cropping systems characterised by minimal inputs (Achu et al., 2005; Achigan Dako et al., 2006; Zoro Bi et al., 2006). C. mannii thus represents an excellent plant model for which improved cropping systems implementation can insure the economic prosperity of rural women from tropical Africa.

In spite of the nutritional and agronomic potentials of $C$. mannii, in depth basic investigations on the crop are scant (Osuji et al., 2006). For example, to our knowledge, no detailed study has been devoted to genetic diversity and reproduction biology. However, investigations reported for others species, suggested that cucurbit family is predominantly outcrossing (Montes-Hernandez and Eguiarte, 2002). Such expectations are based on the fact that indigenous edible-seeded cucurbits are generally monoecious and entomophilous (Gusmini, 2003). The occurrence of auto-incompatibility of $C$. mannii has not been clearly demonstrated, as well as the reproductive mechanisms. In addition, C. mannii appears to be one of the most difficult genera for cytotaxonomic and cytogenetic studies. A recent study related to the ploïdy showed that chromosome counting in $C$. mannii is a tedious manipulation (Osuji et al., 2006).

The first step of such investigation is the documentation and the assemblage of genetic stocks representative of the total genetic diversity displayed by this species (Kjellqvist, 1975; Chapman, 1989; Brown and Briggs, 1991). Results from such investigations are useful to improve both their quality and their productivity through selection and breeding, as well as to implement reliable genetic resources collecting and conservation strategy.

To address these issues, a study is being conducted in Côte d'Ivoire to define the optimal allocation of effort in conservation of these indigenous oilseed cucurbit genetic resources, with special reference to sampling strategy and sample size determination for field collection. Morphological and allozyme markers usually provide reliable data allowing the achievement of the indicated objectives (Erskine and Muehlbauer, 1991; Hamrick and Godt, 1997; Maggs-Kölling et al., 2000; Marr et al., 2007).

The goals of the present study, based on morphological and allozyme markers were as follows: (1) to estimate the amount of genetic diversity within- and among-accessions and cultivars of $C$. mannii; (2) to determine the degree of genetic differentiation and gene flow among accessions; and (3) to examine the phylogenetic relationship between cultivars of the indicated plant material.

\section{Material and methods}

\subsection{Plant material and collecting sites}

Twenty-four accessions of $C$. mannii were selected from an indigenous oilseed cucurbits germplasm collection maintained at the University of Abobo-Adjamé (Abidjan, Côte d'Ivoire). An accession is a sample of fruits or seeds collected in one field or obtained from one farmer's stock. One sample was constituted of many fruits or seeds, according to their availability in farmer's stock. The selected accessions, identified by alpha-numeric codes, were representative of three cultivars (defined on the basis of seed size and designated small-, medium-, and big-seeded) and the three agro-ecological zones (Centre, East and South) of Côte d'Ivoire in which this species is regularly produced. Big seeds' size varies between 125 and $151 \mathrm{~mm}^{2}$, medium seeds from 86 to $110 \mathrm{~mm}^{2}$, and small seeds from 41 to $52 \mathrm{~mm}^{2}$ (Fig. 1) (Zoro Bi et al., 2006). Two to 11 accessions were sampled per cultivar, according to seeds availability (Table 1). The geographical coordinates and ecological traits of sites of the collecting missions are as follows (Zoro Bi et al., 2005):

- The southern zone which is localized between latitudes $4^{\circ} 41 \mathrm{~N}-6^{\circ} 00 \mathrm{~N}$ and longitudes $4^{\circ} 00 \mathrm{~W}-7^{\circ} 30 \mathrm{~W}$. In this zone, rainfalls are abundant (annual mean $>2000 \mathrm{~mm}$ ) and mean annual temperature is $28^{\circ} \mathrm{C}$, with annual amplitude of $5-10^{\circ} \mathrm{C}$. Vegetation is mainly represented by the tropical rain forest, with mangrove on the coastal side.

- The eastern zone which is limited by latitudes $6^{\circ} 00 \mathrm{~N}-8^{\circ} 00 \mathrm{~N}$ and longitudes $3^{\circ} 00 \mathrm{~W}-5^{\circ} 00 \mathrm{~W}$. This zone is characterised by the transitional woodland savannas, with several blocks of semi-deciduous forests. Rainfalls vary from 875 to $1910 \mathrm{~mm}$, with an annual mean of $1250 \mathrm{~mm}$; the annual mean temperature is $27^{\circ} \mathrm{C}$.

- The central zone which is limited by latitudes $6^{\circ} 00 \mathrm{~N}-8^{\circ} 00 \mathrm{~N}$ and longitudes $5^{\circ} 00 \mathrm{~W}-7^{\circ} 00 \mathrm{~W}$. Annual rainfalls vary from 800 to $1400 \mathrm{~mm}$, with an annual mean of $1200 \mathrm{~mm}$; the annual mean temperature is $27^{\circ} \mathrm{C}$. The vegetations are made of various woodland savannas with extended ranges of herbaceous areas. 


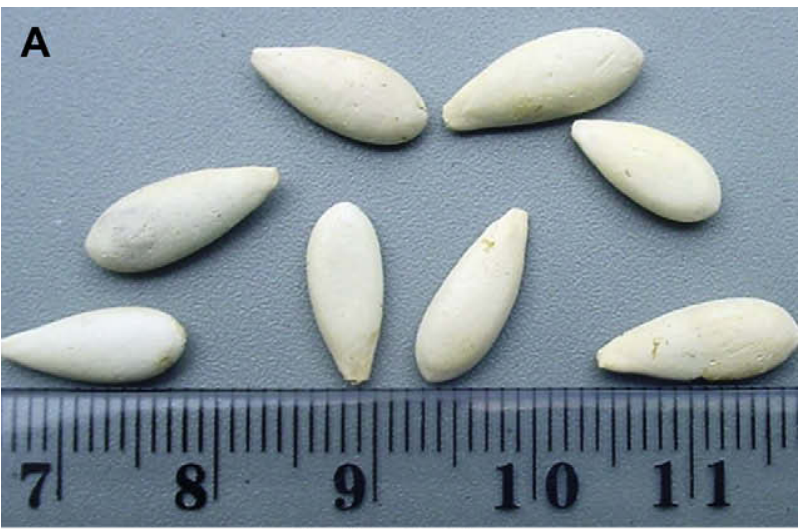

Small seed cultivar

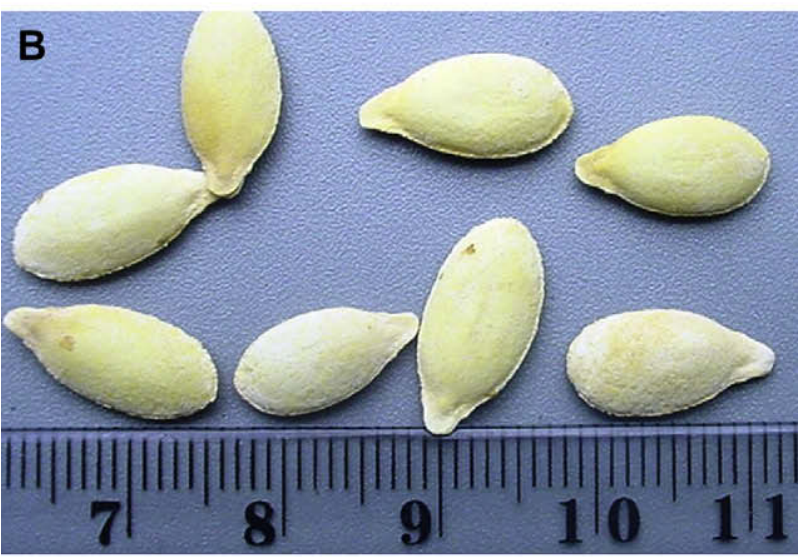

Medium seed cultivar

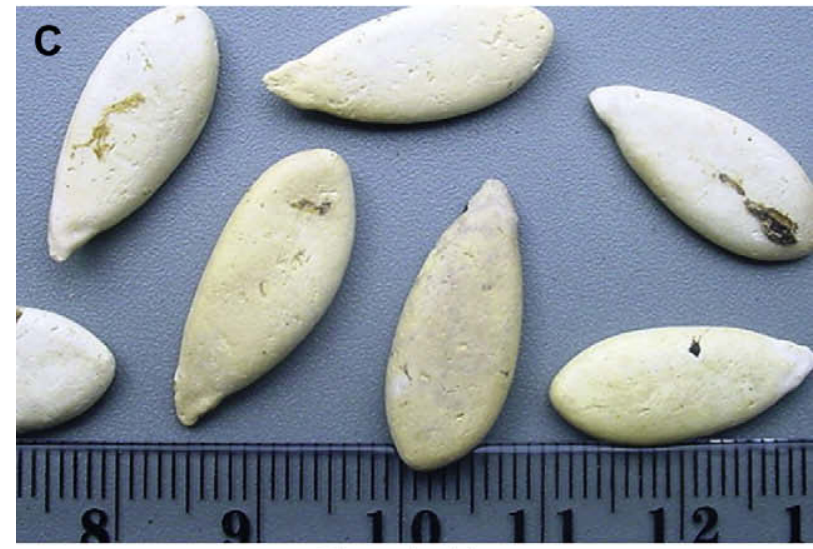

Big seed cultivar

Fig. 1. Seeds of Cucumeropsis mannii Naudin cultivars. A: small-sized seeds; B: medium-sized seeds; C: large-sized seeds.

\subsection{Morphological characterisation}

\subsubsection{Study site and experimental design}

On farm experiment was conducted in the village of Manfla, located in the Centre (latitudes $7^{\circ} 00 \mathrm{~N}-7^{\circ} 26 \mathrm{~N}$ and longitudes $\left.6^{\circ} 00 \mathrm{~W}-6^{\circ} 30 \mathrm{~W}\right) 400 \mathrm{~km}$ north Abidjan, Côte d'Ivoire, during 2005 later (May-November) cropping season to examine morphological variation in C. mannii, using seeds from 16 accessions (Table 1 ). Planting was done according to a completely randomised block design, with three replications. Each plot was $20 \times 30 \mathrm{~m}$ and received $10-18$ holes at a depth of $3 \mathrm{~cm}$, resulting in 30-45 holes per accession. The holes were arranged in rows at spacing of $4 \mathrm{~m}$ between and within rows. The plots were hoe weeded regularly to prevent any interaction between plant materials and weed load. Disease and pest control was 
Table 1

Accession codes, cultivars, collection zones, and size of Cucumeropsis mannii samples used for morphological traits and allozymes analysis

\begin{tabular}{|c|c|c|c|c|c|}
\hline Code & Cultivar & Collection zone & Geographic coordinate & $\begin{array}{l}\text { Sample size } \\
\text { for morphological traits analysis }\end{array}$ & $\begin{array}{l}\text { Sample size } \\
\text { for allozyme analysis }\end{array}$ \\
\hline NI 097 & Big seeds & East & $6^{\circ} 39 \mathrm{~N}-4^{\circ} 11 \mathrm{~W}$ & 9 & 5 \\
\hline NI 129 & Big seeds & Centre & $7^{\circ} 25 \mathrm{~N}-6^{\circ} 02 \mathrm{~W}$ & 9 & 17 \\
\hline NI 165 & Big seeds & East & $6^{\circ} 43 \mathrm{~N}-4^{\circ} 21 \mathrm{~W}$ & 9 & 15 \\
\hline NI 184 & Big seeds & East & $6^{\circ} 38 N-4^{\circ} 11 W$ & 9 & 14 \\
\hline NI 189 & Big seeds & Centre & $7^{\circ} 25 \mathrm{~N}-6^{\circ} 02 \mathrm{~W}$ & 9 & 14 \\
\hline NI $288^{a}$ & Big seeds & East & $7^{\circ} 08 \mathrm{~N}-5^{\circ} 46 \mathrm{~W}$ & - & 19 \\
\hline NI $316^{a}$ & Big seeds & East & $7^{\circ} 10 \mathrm{~N}-5^{\circ} 30 \mathrm{~W}$ & - & 12 \\
\hline $\mathrm{NI} 349^{\mathrm{a}}$ & Big seeds & East & $7^{\circ} 08 \mathrm{~N}-5^{\circ} 46 \mathrm{~W}$ & - & 14 \\
\hline $\mathrm{NI} 363^{\mathrm{a}}$ & Big seeds & East & $7^{\circ} 12 \mathrm{~N}-5^{\circ} 33 \mathrm{~W}$ & - & 13 \\
\hline NI $365^{a}$ & Big seeds & East & $7^{\circ} 12 \mathrm{~N}-5^{\circ} 33 \mathrm{~W}$ & - & 10 \\
\hline NI $369^{a}$ & Big seeds & East & $7^{\circ} 12 \mathrm{~N}-5^{\circ} 33 \mathrm{~W}$ & - & 4 \\
\hline NI 001 & Medium seeds & Centre & $7^{\circ} 25 \mathrm{~N}-6^{\circ} 02 \mathrm{~W}$ & 5 & 15 \\
\hline NI 008 & Medium seeds & Centre & $7^{\circ} 41 \mathrm{~N}-5^{\circ} 01 \mathrm{~W}$ & 5 & 5 \\
\hline NI 030 & Medium seeds & South & $5^{\circ} 17 \mathrm{~N}-3^{\circ} 59 \mathrm{~W}$ & - & 14 \\
\hline NI 089 & Medium seeds & South & $5^{\circ} 17 \mathrm{~N}-3^{\circ} 59 \mathrm{~W}$ & 5 & 14 \\
\hline NI 124 & Medium seeds & East & $5^{\circ} 31 \mathrm{~N}-3^{\circ} 38 \mathrm{~W}$ & 5 & 16 \\
\hline NI 130 & Medium seeds & South & $4^{\circ} 36 \mathrm{~N}-8^{\circ} 20 \mathrm{~W}$ & 5 & 9 \\
\hline NI 132 & Medium seeds & South & $4^{\circ} 30 N-8^{\circ} 30 W$ & 5 & 15 \\
\hline NI $133^{b}$ & Medium seeds & Centre & $7^{\circ} 17 \mathrm{~N}-4^{\circ} 21 \mathrm{~W}$ & 5 & - \\
\hline $\mathrm{NI} 135^{\mathrm{b}}$ & Medium seeds & East & $6^{\circ} 43 N-4^{\circ} 21 W$ & 5 & - \\
\hline NI 173 & Medium seeds & East & $6^{\circ} 43 \mathrm{~N}-4^{\circ} 21 \mathrm{~W}$ & - & 15 \\
\hline NI 175 & Medium seeds & East & $6^{\circ} 39 N-4^{\circ} 11 W$ & 5 & 9 \\
\hline NI 128 & Small seeds & Centre & $7^{\circ} 25 \mathrm{~N}-6^{\circ} 02 \mathrm{~W}$ & 15 & 10 \\
\hline NI 154 & Small seeds & East & $6^{\circ} 43 N-4^{\circ} 21 W$ & 15 & 15 \\
\hline
\end{tabular}

a Accessions used only for the analysis of allozymes.

b Accessions used only for the analysis of morphological traits.

carried out using a carbamate-based insecticide applied when necessary. Plants were guided on trellis. No fertilizer or irrigation was applied at any time for the duration of the trial.

\subsubsection{Traits measurement}

The trials were regularly monitored throughout the growing season and 24 pheno-morphological and agronomic characters selected from those analysed on divers cucurbits (Maggs-Kölling et al., 2000; Morimoto et al., 2005; Marr et al., 2007) were scored. Phenological traits described were time to emergence (ET), tailspins (TT), male flowering (MF), female flowering (FF), and fruit maturity (FM). These traits representing the number of days from planting to the indicated stage were recorded individually for each plant. Flowers were characterised by their diameter (male: MFD and female: FFD) and their peduncle length (male: MFPL and female: FFPL). Leaf sizes (peduncle length: LPL, limb length: LL, and limb width: LWI) were also examined. For each plant, the number of branches from the central taproot (BN) and fruits (FN) were counted, as well as the harvest index (HI). The later trait representing the ratio between the weights of the dried seeds (weighted in $\mathrm{g}$ at about $5 \% \mathrm{RH}$ ) and that of the mother fruit $(\mathrm{kg})$ was estimated following Nerson (2002). Five measurements were performed on fruits: weight (FWE), length (FL), width (FWI), seeds cavity diameter (SCD), and seeds number (SN). Seed traits analysed included the length (SL), width (SWI), tegument percent (TP), and 100-seeds weight (100-SWE). Measurements on flowers, leaves, and fruits as well as 100-seeds weight were scored using five individuals randomly selected on each plant, resulting in 70-145 scores per accession. The number of plants submitted to measurements, varying according to seeds germinated was 14,29 , and 15 individuals, for small-, medium-, and big-seeded cultivar, respectively.

\subsubsection{Morphological data analysis}

Mean values and standard deviations were calculated for each of the morphological characters in each accession and cultivars. A fixed-effects model ANOVA was performed to check morphological variations between and within cultivars using Minitab ${ }^{\text {TM }}$ Statistical Package (Minitab, 1998). For each character, when the null hypothesis related to the ANOVA was rejected, multiple comparisons using the Least Significant Difference (LSD) test were carried out to determine differences between cultivars. All LSD tests were carried out at $\alpha=0.05$ significance level.

Principal Components Analysis (PCA) with Statistica Software Package (Statistica, 1995) was applied to analyse morphological variation and to assess differences between accessions and cultivars. PCA is particularly relevant to identify variables which most contribute to the value of each principal component. Prior to PCA, the average values of the traits were standardised according the formula:

$$
\text { standardised data }=\frac{\text { sample estimates }- \text { mean }}{\text { standard deviation }} .
$$


This standardisation is required to reach the same scale for all the characters (Dagnelie, 1986). A phenogram was developed with unweighted pair group method arithmetic (UPGMA) using an Euclidian distances matrix to examine the phylogenetic relationship between cultivars and accessions.

\subsection{Allozymes analysis}

\subsubsection{Plant materials and genetic characterisation}

Twenty-two accessions representative of the three cultivars originating from the three collection zones were selected for allozymes variability analysis, with 4-19 seeds per accession. Differences between samples size were mainly due to the difference in the germination rates among accessions.

For electrophoretic variation, we analysed seven readable and reproducible enzyme loci resolved from six enzymatic systems: colorimetric esterases (cEST, E.C. 3.1.1.-), isocitrate dehydrogenase (IDH, E.C. 1.1.1.42), malate dehydrogenase (MDH, E.C. 1.1.1.37), shikimate dehydrogenase (SKDH, E.C. 1.1.1.25), peroxydases (PER, E.C. 1.11.1.7), and superoxide dismutase (SOD, E.C. 1.15.1.1).

Enzyme extraction was done following Knerr et al. (1989) and Staub et al. (1997), with minor modifications. Thus, $0.01 \mathrm{~g}$ of leave tissues from 7 to 14-day-old seedlings was grinded in $0.1 \mathrm{~mL}$ of $0.045 \mathrm{M} \mathrm{TRIS}-\mathrm{HCl}, \mathrm{pH} 7.1$, containing $0.05 \%(\mathrm{v} / \mathrm{v})$ triton $\mathrm{X}-100$, and $0.1 \%$ 2-mercaptoethanol. Electrophoresis was performed using a horizontal $12 \%$ starch gels containing $3 \%$ sucrose. The continuous morpholine-citrate, pH 6.1 (Wendel and Weeden, 1989) was employed for electrophoresis. The techniques for gel electrophoresis and histochemical staining procedures were those reported by Zoro Bi et al. (1999).

Loci were labeled sequentially, with those migrating closest to the anodal end designated as number 1 . The accession NI 134 submitted to several cycles of selfing, was used as the control for our analyses.

For each locus, the putative allozyme specifying approach was used. For all loci surveyed, bands showed segregation patterns characteristics of either dimeric or monomeric codominant enzymes, although a formal genetic analysis was not made. Thus, our estimates of genetic variability index could be compared with those found in more general surveys of genetic variation.

\subsubsection{Genetic diversity and accession-level homozygosity}

Most of the following statistical genetic variability parameters were computed by the software Gensurvey (Vekemans and Lefèbvre, 1997). To estimate accession-level genetic variability, the genotypic frequencies data were used to calculate the proportion of polymorphic loci ( $P$; $99 \%$ criterion), the mean number of alleles per locus $(A)$, the effective number of alleles per locus $\left(A_{\mathrm{e}}\right)$, the observed $\left(H_{0}\right)$ and expected $\left(H_{\mathrm{e}}\right)$ heterozygosity corrected for small sample size (Nei, 1987).

Wright's $F\left[F=\left(1-H_{\mathrm{o}} / H_{\mathrm{e}}\right)\right]$, the inbreeding coefficient, measures deviation of population genotypic composition from Hardy-Weinberg $(\mathrm{H}-\mathrm{W})$ expectations. If inbreeding is avoided, $F=0$; negative $F$ indices are usually due to selection in favour of the heterozygotes whereas positive values indicate that the considered population has an inbreeding system of mating. The deviation of the analysed accessions genotypic composition from the expected Hardy-Weinberg proportions was tested using an exact test performed by the software Genepop (Raymond and Rousset, 1995).

\subsubsection{Genetic structure and gene flow}

The partitioning of total genetic diversity into within- and among-accessions components was examined using Nei's (1987) genetic diversity statistics. For each polymorphic locus, total gene diversity $\left(H_{\mathrm{T}}\right)$ was partitioned into diversity within $\left(H_{\mathrm{S}}\right)$ and among $\left(D_{\mathrm{ST}}\right)$ accessions as $H_{\mathrm{T}}=H_{\mathrm{S}}+D_{\mathrm{ST}}$. A measure of genetic differentiation among accessions $\left(G_{\mathrm{ST}}\right)$ was calculated at each polymorphic locus $\left(G_{\mathrm{ST}}=D_{\mathrm{ST}} / H_{\mathrm{T}}\right)$. Theoretically, $G_{\mathrm{ST}}$ ranges from zero (all genetic variation maintained within accessions) to 1 (all genetic variation maintained among accessions). For each locus, the degree of accessions genetic structuring was investigated by Wright's F-statistics calculated following Weir and Cockerham's (1984). These quantities measure the degree of relatedness of various pairs of alleles: Wright's $F_{\mathrm{TT}}$, the correlation of alleles within individuals over all accessions, measures the heterozygotes deficiency in a set of accessions; $F_{\mathrm{ST}}$, the correlation of alleles of different individuals in the same population, measures the accessions genetic differentiation due to genetic drift; and $F_{\mathrm{IS}}$, the correlation of alleles within individuals within a population, is interpreted as intra-accession heterozygotes deficiency. Gene flow among accessions was estimated indirectly from accessions genetic structure statistics. The number of migrants into a accession per generation $\left(N_{\mathrm{m}}\right)$ was estimated using Wright's (1951) equation as modified by Crow and Aoki $(1984): F_{\mathrm{ST}}=1 /\left(4 N_{\mathrm{m}} \alpha+1\right)$ where $\alpha=[n /(n-1)]^{2}$ and $n$ is the number of populations. For our data, we used $G_{\mathrm{ST}}$, which is the multiallelic equivalent of Wright's $F_{\text {ST. }}$.

A dendrogram was constructed based on Nei's genetic distances matrix data by applying the UPGMA group analysis using the software Phylip's Consence procedure (Felsentein, 1993). The reliability and robustness of the dendrogram were tested by bootstrap analysis with 1000 replications.

\section{Results}

\subsection{Morphological characterisation}

Table 2 documents the ranges of morphological variation among cultivars and the results of statistical analyses performed to test difference between them. The ANOVA highlighted significant difference among cultivars for 20 traits out of 24 
Table 2

Average of 20 morphological and agronomic traits scored in three cultivars of Cucumeropsis mannii and results of comparison tests

\begin{tabular}{|c|c|c|c|c|c|}
\hline \multirow[t]{2}{*}{ Characters $^{\mathrm{a}}$} & \multicolumn{3}{|c|}{ Mean values ( \pm SD) per cultivar (number of plants analysed) } & \multicolumn{2}{|c|}{ Statistic parameters } \\
\hline & Small seeds (31) & Medium seeds (40) & Big seeds (41) & $F$ & $P$ \\
\hline ET $(d)$ & $013.096 \pm 0.707^{\mathrm{a}}$ & $13.000 \pm 2.121^{\mathrm{a}}$ & $11.780 \pm 0.000^{\mathrm{b}}$ & 8.42 & 0.015 \\
\hline TT (d) & $032.161 \pm 2.067^{\mathrm{a}}$ & $28.175 \pm 3.129^{b}$ & $29.268 \pm 2.230^{\mathrm{b}}$ & 22.2 & $<0.001$ \\
\hline $\operatorname{MF}(d)$ & $102.540 \pm 1.177^{\mathrm{a}}$ & $103.990 \pm 1.090^{\mathrm{a}}$ & $120.750 \pm 1.110^{\mathrm{b}}$ & 22.61 & $<0.001$ \\
\hline $\mathrm{FF}(\mathrm{d})$ & $116.490 \pm 19.300^{a}$ & $121.800 \pm 17.27^{\mathrm{a}}$ & $137.780 \pm 13.00^{b}$ & 16.94 & $<0.001$ \\
\hline $\mathrm{FFD}(\mathrm{cm})$ & $001.990 \pm 0.297^{\mathrm{a}}$ & $0.310 \pm 0.27^{\mathrm{b}}$ & $2.350 \pm 0.210^{\mathrm{b}}$ & 19.75 & $<0.001$ \\
\hline FFPL $(\mathrm{cm})$ & $004.370 \pm 0.76^{\mathrm{a}}$ & $4.690 \pm 0.66^{\mathrm{a}}$ & $5.570 \pm 0.71^{b}$ & 28.11 & $<0.001$ \\
\hline $\operatorname{LL}(\mathrm{cm})$ & $012.753 \pm 1.32^{\mathrm{a}}$ & $13.930 \pm 1.50^{b}$ & $13.850 \pm 1.15^{\mathrm{b}}$ & 8.2 & $<0.001$ \\
\hline LWI (cm) & $015.143 \pm 1.48^{a}$ & $16.230 \pm 1.48^{\mathrm{b}}$ & $15.194 \pm 1.55^{a}$ & 6.29 & 0.003 \\
\hline $\mathrm{BN}$ & $004.516 \pm 1.363^{\mathrm{a}}$ & $5.475 \pm 1.867^{\mathrm{b}}$ & $4.585 \pm 1.596^{\mathrm{a}}$ & 4.05 & 0.040 \\
\hline FN & $017.810 \pm 1.655^{\mathrm{a}}$ & $18.640 \pm 1.51^{\mathrm{a}}$ & $5.220 \pm 1.775^{\mathrm{b}}$ & 76.28 & $<0.001$ \\
\hline FWE (g) & $508.100 \pm 163.5^{a}$ & $621.100 \pm 193.7^{b}$ & $876.700 \pm 180.90^{c}$ & 40.25 & $<0.001$ \\
\hline $\mathrm{SCD}(\mathrm{cm})$ & $006.190 \pm 0.51^{\mathrm{a}}$ & $6.440 \pm 0.78^{a}$ & $7.165 \pm 0.750^{\mathrm{b}}$ & 19.08 & $<0.001$ \\
\hline $\mathrm{FL}(\mathrm{cm})$ & $008.644 \pm 0.674^{\mathrm{a}}$ & $9.103 \pm 1.195^{a}$ & $0.230 \pm 1.150^{\mathrm{b}}$ & 22.13 & $<0.001$ \\
\hline FWI & $013.992 \pm 2.136^{\mathrm{a}}$ & $15.080 \pm 1.900^{\mathrm{b}}$ & $15.590 \pm 2.080^{\mathrm{b}}$ & 5.51 & 0.005 \\
\hline FN & $326.000 \pm 84.33^{a}$ & $361.980 \pm 60.200^{b}$ & $209.900 \pm 59.310^{b}$ & 55.64 & $<0.001$ \\
\hline $\mathrm{SL}(\mathrm{mm})$ & $011.610 \pm 0.08^{a}$ & $14.220 \pm 0.253^{b}$ & $17.519 \pm 5.282^{c}$ & 92.09 & $<0.001$ \\
\hline SWI (mm) & $005.220 \pm 0.610^{\mathrm{a}}$ & $6.080 \pm 0.37^{b}$ & $7.370 \pm 0.693^{c}$ & 127.93 & $<0.001$ \\
\hline 100-SWE (mg) & $001.206 \pm 0.2190^{\mathrm{a}}$ & $1.270 \pm 00.17^{a}$ & $0.717 \pm 0.249^{\mathrm{b}}$ & 76.28 & $<0.001$ \\
\hline $\mathrm{HI}$ & $000.045 \pm 0.022^{\mathrm{a}}$ & $0.054 \pm 00.01^{a}$ & $0.024 \pm 0.010^{\mathrm{b}}$ & 33.47 & $<0.001$ \\
\hline TP (\%) & $019.526 \pm 9.289^{a}$ & $20.240 \pm 7.809^{a}$ & $10.540 \pm 6.300^{\mathrm{b}}$ & 19.11 & $<0.001$ \\
\hline
\end{tabular}

${ }^{\text {a }}$ For each trait, mean values followed by the same superscript were not significantly different $(p \geq 0.05)$.

measured. Three traits (FWE, SL and SWI) differentiated completely the three cultivars, while the 17 remaining traits allowed partial distinctions.

Correlation coefficients computed for all pairs of traits (data not shown) revealed significantly positive values for 10 pairs, MFD-FF: 0.758; MFPL-FFPL: 0.759; LL-LWI: 0.681; LPL-BN: 0.652; FL-FN: 0.621; FWE-SCD: 0.716; SN-FWI: 0.709; SL-100SWE: 0.665; SWI-ET: 0.816; HI-TP: 0.886 and negative values for eight pairs, FN-MF: -0.588 ; FN-FF: -0.572 ; FWE-BN: -0.550 ; SL-FN: -0.511; SWI-FN: -0.537; HI-FWE: -0.577; HI-SCD: -0.514; HI-FF: -0.506 . To avoid redundancy, 10 variables presenting high positive correlation have been discarded and PCA was performed using data related to 14 traits. The five first principal factor (with eigenvalues $>1$ ) loadings and their contributions are shown in Table 3. The cumulative contribution of the first (PC1) to fifth (PC5) component was $64.746 \%$ of the total variability among the 24 accessions, with 23.883 , $16.362,8.877,8.298$, and 7.323\% for PC1, PC2, PC3, PC4, and PC5, respectively (Table 3). The number of fruits per plant (FN) and seeds per fruit (SN) was highly and positively correlated with PC1, on the other hand male flower peduncle length (MFPL) and fruit weight (FWE) were negatively correlated with PC1. This result indicated that this axis was determined by the fruit yield and male floral size. The second axis was correlated positively to the time to tailspins (TT) and negatively to the number of branch from central taproot (BN). PC3, PC4, and PC5 were correlated to days to female flowering (FF), fruit maturity (FM) and male flowering (MF), respectively. These results suggested that PC4 and PC5 were determined by earliness.

Table 3

Eigenvectors, eigenvalues, and percent variance explained by the first five principal components (PCs) for 14 traits analysed in 16 accessions of $C$. mannii

\begin{tabular}{|c|c|c|c|c|c|}
\hline \multirow[t]{2}{*}{ Traits } & \multicolumn{5}{|c|}{ Eigenvectors } \\
\hline & PC 1 & PC 2 & PC 3 & PC 4 & PC 5 \\
\hline$\overline{\text { ET }}$ & 0.475 & 0.318 & -0.157 & 0.105 & 0.190 \\
\hline TT & 0.1468 & $0.734^{*}$ & 0.282 & -0.113 & -0.243 \\
\hline MF & -0.578 & 0.342 & 0.096 & 0.040 & 0.721 * \\
\hline $\mathrm{FF}$ & -0.334 & 0.111 & $-0.700^{*}$ & -0.380 & -0.261 \\
\hline FFD & -0.485 & -0.326 & -0.421 & 0.255 & 0.224 \\
\hline MFPL & $-0.715^{*}$ & 0.0547 & -0.466 & -0.412 & 0.101 \\
\hline LL & -0.584 & -0.162 & 0.009 & -0.263 & 0.330 \\
\hline $\mathrm{BN}$ & 0.118 & $-0.742^{*}$ & 0.239 & -0.160 & 0.335 \\
\hline FM & -0.279 & 0.197 & 0.091 & $0.766^{*}$ & 0.240 \\
\hline FN & 0.799* & -0.381 & -0.051 & -0.244 & 0.184 \\
\hline FWE & $-0.774^{*}$ & -0.195 & 0.082 & 0.262 & -0.036 \\
\hline SN & $0.752^{*}$ & -0.160 & -0.268 & 0.188 & 0.371 \\
\hline 100-SWE & -0.311 & -0.516 & -0.119 & 0.475 & -0.407 \\
\hline $\mathrm{TP}$ & 0.570 & -0.073 & -0.572 & 0.292 & -0.073 \\
\hline Eigenvalue & 3.890 & 1.996 & 1.147 & 1.120 & 1.083 \\
\hline$\%$ of variance explained & 23.883 & 16.362 & 8.877 & 8.298 & 7.324 \\
\hline Cumulative $\%$ of variance explained & 23.883 & 40.246 & 49.124 & 57.422 & 64.746 \\
\hline
\end{tabular}

* Significant correlation values. 
Fig. 2 shows the position of the accessions in relation to the two principal components. On the basis of their average linkage to axes, the 58 individuals analysed were grouped into three aggregates, corresponding to the three cultivars analysed. The groups I, II, and III were mainly composed of individuals from the small-, medium-, and big-seeded cultivars, respectively. The groups with small- (I) and big-seeded (III) cultivars were positioned on the opposite sides of the axis 1 and separated by this of the medium-seeded cultivar (II). Note that two individuals of the big-seeded cultivar were included in the group II. Individuals of group II were the most widely distributed along both side of axis 1 , indicating the greatest morphological variability within the cultivar with medium-size seeds, compared to the two others. The positions of the three groups on the plan determined by the two principal components (axis 1-axis 2) indicated that the small-seeded cultivar (group I) was characterised by a delayed germination and a high yield expressed in terms of fruits' and seeds' numbers per plant. Individuals of the medium-seeded cultivar (group II) were mainly differentiated by their high number of ramification, coupled with large leaf sizes. Contrarily, the big-seeded cultivar was composed of plants with long maturation time and bearing relatively big flowers, heavy fruits and containing the lowest number of seeds.

The phenogram (Fig. 3), based on the unweighted pair group method arithmetic (UPGMA) using a Euclidian distances matrix, subdivided the accessions analysed into two major groups: group I comprising accessions of small- and mediumseeded cultivars and group II mainly composed of cultivar with big seeds. Nevertheless, we noted the presence of one accession (NI 130) from the medium-seeded cultivar in this group. In each of the two groups, the distribution of accessions determined two subgroups, corresponding to the collecting sites. Thus, in the group I, accessions collected in Centre (NI 001, NI 008, NI 128, and NI 133) or in South (NI 089 and NI 132), and one accession from East (NI 154) forming the subgroup I1, were distinguished from those from the East exclusively (NI 124, NI 135, and NI 175) (subgroup I2). In the group II, two accessions from Centre (NI 129 and NI 189) and one accession from South (NI 130) determined the subgroup II1 while those collected in the East (NI 097, NI 165, and NI 184) were grouped into subgroup II2.

The statistical analyses performed to test morphological differences between accessions of each cultivar on the basis of their collecting sites, showed that nine (TT, LWI, FWE, SCD, FWI, FL, SL, 100-SWE, and TP), eight (ET, TT, MF, FF, FFD, LPL, FN, and SCD), and five (FM, SN, SWI, 100-SWE, and HI) traits out of 24 varied significantly $(p<0.05)$ for the big-, medium- and small-seeded cultivars, respectively (data not shown). These data suggest that the morphological differences between accessions belonging to the same cultivar but collected in distinct geographical zones are not important.

\subsection{Allozymes variability}

\subsubsection{Genetic diversity}

A total of seven readable and reproducible enzymes loci with 10 alleles were observed in the 22 accessions. Three of the seven loci (Mdh-1, Mdh-3, and $S k d h)$ were polymorphic in at least one accession, with two alleles. One monomorphic locus controlled cEST and SOD, and two monomorphic loci controlled PER.

The proportion of polymorphic loci $(P)$ evaluated at $99 \%$ criterion varied from 0 to $33.30 \%$, with a mean of $9.96 \%$ (Table 4 ). This estimates equalled to $14.30 \%$ for each of the three cultivar analysed. The mean number of alleles per locus $(A)$ and the effective number of alleles per locus $\left(A_{\mathrm{e}}\right)$, varied, respectively, from 1 to 1.30 with a mean of $1.10 \pm 0.11$ and from 1 to 1.20 with a mean of $1.02 \pm 0.04$. As shown in Table 4, the average $H_{0}$ was $0.023 \pm 0.033$, ranging from 0 to 0.095 . $H_{0}$ equalled to zero for the small seeds cultivar and 0.029 and 0.027 for the medium and big seed cultivar, respectively. The average $H_{\mathrm{e}}$ was $0.038 \pm 0.046$, ranging from 0 to 0.178 . These results indicated that in the $C$. mannii collection analysed, enzyme loci express a low allelic richness $(A=1.10 \pm 0.11)$, the polymorphic loci presenting unbalanced allele frequencies $\left(A_{\mathrm{e}}=1.02 \pm 0.04\right)$.

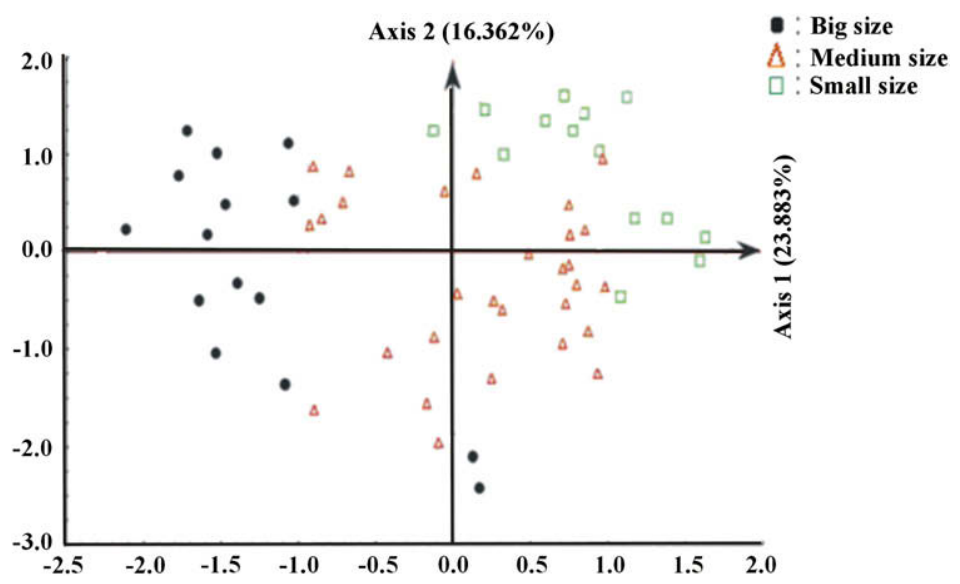

Fig. 2. Scattered diagram of 16 Cucumeropsis mannii accessions for the first two PCs. The squares, triangles, and dots represent individuals from group I, group II and group III, respectively. 


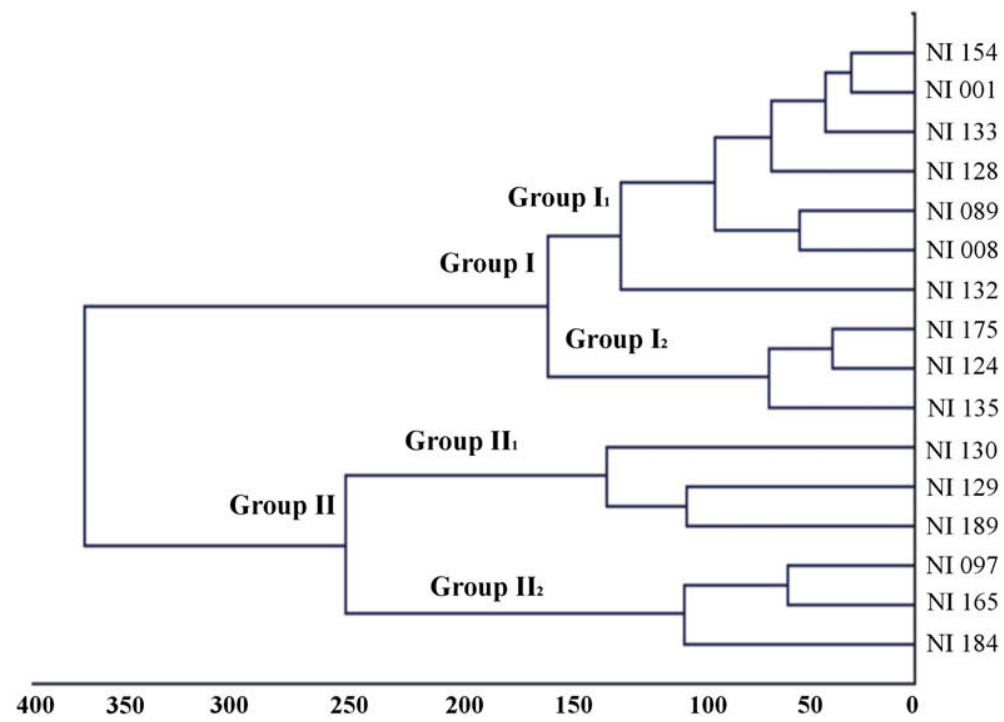

Fig. 3. Dendrogram of 16 accessions constructed using an UPGMA group analysis method based on Euclidian distance from morphological data.

In general, observed genotype frequencies were not significantly different from $\mathrm{H}-\mathrm{W}$ expectations (Table 4). Indeed, of the 14 inbreeding coefficients calculated, only four (28.57\%) were significantly different from zero $(\alpha=0.05)$. Such results were obtained from locus $S k d h$ in accession NI 128, Mdh-3 in accession NI 129, Mdh-1 in accession NI 129, and at Skdh in accession NI $369\left(H_{0}=0 ; F=+1\right.$ in each $)$.

Table 4

Accession acronyms (alpha-numeric codes), sample sizes, ${ }^{\text {a }}$ estimates of genetic diversity, ${ }^{\text {b }}$ and summary of results of tests for deviations of genotypic frequencies from Hardy-Weinberg equilibrium in 22 accessions of $C$. mannii

\begin{tabular}{|c|c|c|c|c|c|c|c|c|c|c|c|}
\hline \multirow[t]{2}{*}{ Accessions $(N)$} & \multirow[t]{2}{*}{ Cultivar } & \multicolumn{5}{|c|}{ Genetic diversity indices } & \multirow[t]{2}{*}{$F_{\mathrm{IS}}$} & \multicolumn{4}{|c|}{$\mathrm{H}-\mathrm{W}$ deviations } \\
\hline & & $A$ & $A_{\mathrm{e}}$ & $P(\%)$ & $H_{\mathrm{o}}$ & $H_{\mathrm{e}}$ & & Tests & $\mathrm{HE}$ & HD & NS \\
\hline NI 128 (10) & $\mathrm{S}$ & 1.100 & 1.040 & 14.300 & 0.000 & 0.071 & 1.000 & 1 & 0 & 1 & 0 \\
\hline NI 154 (15) & $S$ & 1.000 & 1.000 & 0.000 & 0.000 & 0.000 & - & 0 & - & - & - \\
\hline NI 001 (15) & M & 1.000 & 1.000 & 0.000 & 0.000 & 0.000 & - & 0 & - & - & - \\
\hline NI 008 (5) & M & 1.000 & 1.000 & 0.000 & 0.000 & 0.000 & - & 0 & - & - & - \\
\hline NI 030 (14) & M & 1.300 & 1.200 & 28.600 & 0.086 & 0.088 & 0.029 & 2 & 1 & 1 & 1 \\
\hline NI 089 (9) & M & 1.100 & 1.000 & 14.300 & 0.064 & 0.052 & -0.218 & 1 & 1 & 0 & 1 \\
\hline NI 124 (16) & M & 1.100 & 1.040 & 0.000 & 0.040 & 0.035 & -0.130 & 1 & 1 & 0 & 1 \\
\hline NI 130 (9) & M & 1.300 & 1.040 & 14.300 & 0.000 & 0.110 & 1.000 & 2 & 0 & 1 & 0 \\
\hline NI 132 (15) & M & 1.000 & 1.000 & 0.000 & 0.000 & 0.000 & - & 0 & - & - & - \\
\hline NI 173 (15) & M & 1.100 & 1.002 & 14.300 & 0.067 & 0.053 & -0.262 & 1 & 1 & 0 & 1 \\
\hline NI 175 (9) & M & 1.000 & 1.000 & 0.000 & 0.000 & 0.000 & - & 0 & - & - & - \\
\hline NI 097 (5) & B & 1.000 & 1.000 & 0.000 & 0.000 & 0.000 & - & 0 & - & - & - \\
\hline NI 129 (17) & B & 1.100 & 1.000 & 14.300 & 0.000 & 0.055 & 1.000 & 1 & 0 & 1 & 0 \\
\hline NI 165 (15) & B & 1.100 & 1.002 & 14.300 & 0.042 & 0.037 & -0.140 & 1 & 1 & 0 & 1 \\
\hline NI 184 (14) & B & 1.000 & 1.000 & 0.000 & 0.000 & 0.000 & - & 0 & - & - & - \\
\hline NI 189 (14) & B & 1.000 & 1.000 & 0.000 & 0.000 & 0.000 & - & 0 & - & - & - \\
\hline NI 288 (19) & B & 1.100 & 1.000 & 14.300 & 0.036 & 0.032 & -0.150 & 1 & 1 & 0 & 1 \\
\hline NI 316 (12) & B & 1.100 & 1.002 & 14.300 & 0.095 & 0.066 & -0.452 & 1 & 1 & 0 & 1 \\
\hline NI 349 (14) & B & 1.000 & 1.000 & 0.000 & 0.000 & 0.000 & - & 0 & - & - & - \\
\hline NI 363 (13) & B & 1.000 & 1.000 & 0.000 & 0.000 & 0.000 & - & 0 & - & - & - \\
\hline NI 365 (10) & B & 1.100 & 1.002 & 14.300 & 0.071 & 0.056 & -0.270 & 1 & 1 & 0 & 1 \\
\hline NI 369 (4) & B & 1.300 & 1.040 & 33.300 & 0.000 & 0.178 & 1.000 & 1 & 0 & 1 & 0 \\
\hline Mean & & 1.100 & 1.016 & 9.960 & 0.023 & 0.038 & 0.204 & & & & \\
\hline SE & & 0.110 & 0.043 & 10.690 & 0.033 & 0.046 & 0.599 & & & & \\
\hline
\end{tabular}

$P$ is the percentage of polymorphic loci, $A$ is the mean number of alleles per locus, $A_{\mathrm{e}}$ is the effective number of alleles per locus, $H_{\mathrm{o}}$ is the observed heterozygosity, and $H_{\mathrm{e}}$ is the heterozygosity expected under Hardy-Weinberg equilibrium, $F_{\mathrm{IS}}$ is the inbreeding coefficient.

Tests indicate the number of loci for which tests could be performed: HE represents the number of loci with a significant excess of heterozygotes, HD represents the number of loci with a significant deficiency of heterozygotes, and NS represents the number of loci with non-significant inbreeding coefficients. SE is the standard error.

${ }^{\text {a }} N$ is the number of seeds analysed.

b S: small-seeded cultivar, M: medium-seeded cultivar, B: big-seeded cultivar. 


\subsubsection{Genetic structure, gene flow and phylogenetic relationship among accessions}

The estimates of population genetic structure using Nei's genetic diversity statistics are shown in Table 5. The average total heterozygosity $\left(H_{\mathrm{T}}\right)$ and intra-accession genetic diversity $\left(H_{\mathrm{S}}\right)$ were $0.120 \pm 0.056$ and $0.078 \pm 0.022$, respectively. The interaccession genetic diversity $\left(D_{\mathrm{ST}}\right)$ and the coefficient of genetic differentiation among accessions ( $G_{\mathrm{ST}}$ ) averaged to $0.042 \pm 0.036$ and $0.322 \pm 0.129$, respectively. The results indicated that in C. mannii, about $32 \%$ of the total genetic diversity is among accessions, $78 \%$ representing intra-accession genetic diversity. The low genetic differentiation among accessions $\left(G_{\mathrm{ST}}=0.322 \pm 0.129\right)$ and inter-accession genetic diversity $\left(D_{\mathrm{ST}}=0.043 \pm 0.036\right)$ were probably indicative of a relatively high gene flow, which was confirmed by the estimates of the number of migrants per generation $\left(N_{\mathrm{m}}=0.573\right)$ based on Wright's equation. Indeed, such a value indicated that on average, one individual migrated in a given accession (seed stock or field) each two generations. The mean inbreeding index $\left(F_{\mathrm{IT}}\right)$ for the 22 accessions was 0.568 (Table 5 ). This relatively high value showed an important deficiency in heterozygosity. The average $F_{\mathrm{IS}}$ of 0.394 indicated a slight deficit of heterozygotes within accessions. On the other hand, the average $F_{\mathrm{ST}}$ of 0.274 showed a low genetic differentiation among accessions. The UPGMA phylogenetic tree based on the Nei's genetic distances matrix from allozymes data is shown in Fig. 4. The grouping of accessions among the branches of the dendrogram corresponded neither to cultivar nor to the collecting sites. In addition, a clear accessions grouping supported by relatively high number of bootstrap was not observed.

\section{Discussion}

\subsection{Morphological characterisation}

To maintain, evaluate and utilise germplasm efficiently, it is important to investigate the extent of genetic diversity available. Morphological characterisation is an important step in the description and classification of crop germplasm because a breeding programme mainly depends upon the magnitude of morpho-phenological variability (Smith et al., 1991). The morphological traits analysed on C. mannii highlighted an important variability and allowed a clear distinction of the cultivars studied. To our knowledge, studies reporting morphological diversity of $C$. mannii are not published. Consequently, we could not compare data obtained in the present study to others for a best appreciation of the morphological diversity of $C$. mannii cultivar from Côte d'Ivoire. However, the collecting sites of plant materials analysed in the present study being outside their probable zones of origin (East Bissau Guinea, and South Angola, Uganda and Sudan) (Egunjobi and Adebisi, 2004), the level of variability observed was not expected to be among the highest. The traits that contributed significantly to cultivars distinction are those related to yield (sizes and weight of fruits and seeds).

The pattern of morphological variability observed in this study is similar to those from several studies demonstrating that in domesticated crops species, morphological differences are often based on agronomic traits (Maggs-Kölling et al., 2000; Ferriol et al., 2004; Morimoto et al., 2005). In the cucurbit family, the significant contribution of fruit and seed traits to morphological variability has been reported for watermelon (Maggs-Kölling et al., 2000; Gusmini, 2003), bottle gourd (Morimoto et al., 2005), bitter gourd (Dey et al., 2006) and squash (Paris, 2001). Such observation can be explained by the fact that traditional farmers' selection process is mainly driven by specific socio-cultural preferences and use practices. Morphological divergence observed among $C$. mannii cultivars was also related to their reproductive performance. Big-seeded cultivar produces low number of fruits per plant and seeds per fruit. Such negative correlation between fruit and seed size and plant's fruit load could be attributed to the regulatory behavior of plants, mainly due to external resources limitation. Such observations are widely reported for cucurbits (Nerson, 2005; Ban et al., 2006).

In the analysis made to estimate the relative contributions of the different traits studied towards the overall phenotypic variation among the 16 accessions, a total of five principal components (PCs), having eigenvalues beyond the minimal threshold of one, explained as much as $65 \%$ of the entire diversity in all the 14 traits evaluated (Table 3 ). About $24 \%$ of the accession variability explained by the first PC alone was due chiefly to variations in fruit and seed yields. We could thus conclude that seed size proved to be a useful tool for separating C. mannii cultivars. More interestingly, the individuals analysed were grouped into three groups, corresponding to the three cultivars defined on the basis of seed size (Fig. 2). These

Table 5

Nei's (1987) genetic diversity indices, F-statistics, and estimates of inter-accession gene flow

\begin{tabular}{|c|c|c|c|c|c|c|c|c|}
\hline \multirow[t]{2}{*}{ Locus } & \multicolumn{4}{|c|}{ Nei’s genetic diversity indices } & \multicolumn{3}{|c|}{ F-statistics } & \multirow{2}{*}{$\frac{\text { Gene flow }}{N_{\mathrm{m}}}$} \\
\hline & $H_{\mathrm{T}}$ & $H_{\mathrm{S}}$ & $D_{\mathrm{ST}}$ & $G_{\mathrm{ST}}$ & $F_{\mathrm{IT}}$ & $F_{\mathrm{IS}}$ & $F_{\mathrm{ST}}$ & \\
\hline$\overline{M d h-1}$ & 0.185 & 0.101 & 0.084 & 0.452 & 0.496 & 0.123 & 0.426 & 0.278 \\
\hline Mdh-3 & 0.093 & 0.075 & 0.018 & 0.194 & 0.207 & 0.059 & 0.158 & 0.954 \\
\hline Skdh & 0.084 & 0.057 & 0.027 & 0.320 & 1.000 & 1.000 & 0.238 & 0.488 \\
\hline Mean & 0.120 & 0.078 & 0.042 & 0.322 & 0.568 & 0.394 & 0.274 & 0.573 \\
\hline SE & 0.056 & 0.022 & 0.036 & 0.129 & 0.401 & 0.526 & 0.138 & 0.346 \\
\hline
\end{tabular}

Notes: $H_{\mathrm{T}}$, the total genetic diversity; $H_{\mathrm{S}}$, the genetic diversity within accessions; $D_{\mathrm{ST}}$, the genetic diversity among accessions; $G_{\mathrm{ST}}$, the among-accessions gene differentiation coefficient; $F_{\mathrm{IT}}$, the mean inbreeding coefficient of a set of accessions; $F_{\mathrm{IS}}$, the fixation index related to non-random mating within populations; $F_{\mathrm{ST}}$, the inter-accession genetic differentiation due to genetic drift; $N_{\mathrm{m}}$, the gene flow estimates according to Wright's (1951) equation. Such a value indicated that on average, one individual migrated in a given accession (seed stock or field) per generation; and SE, the standard error. 


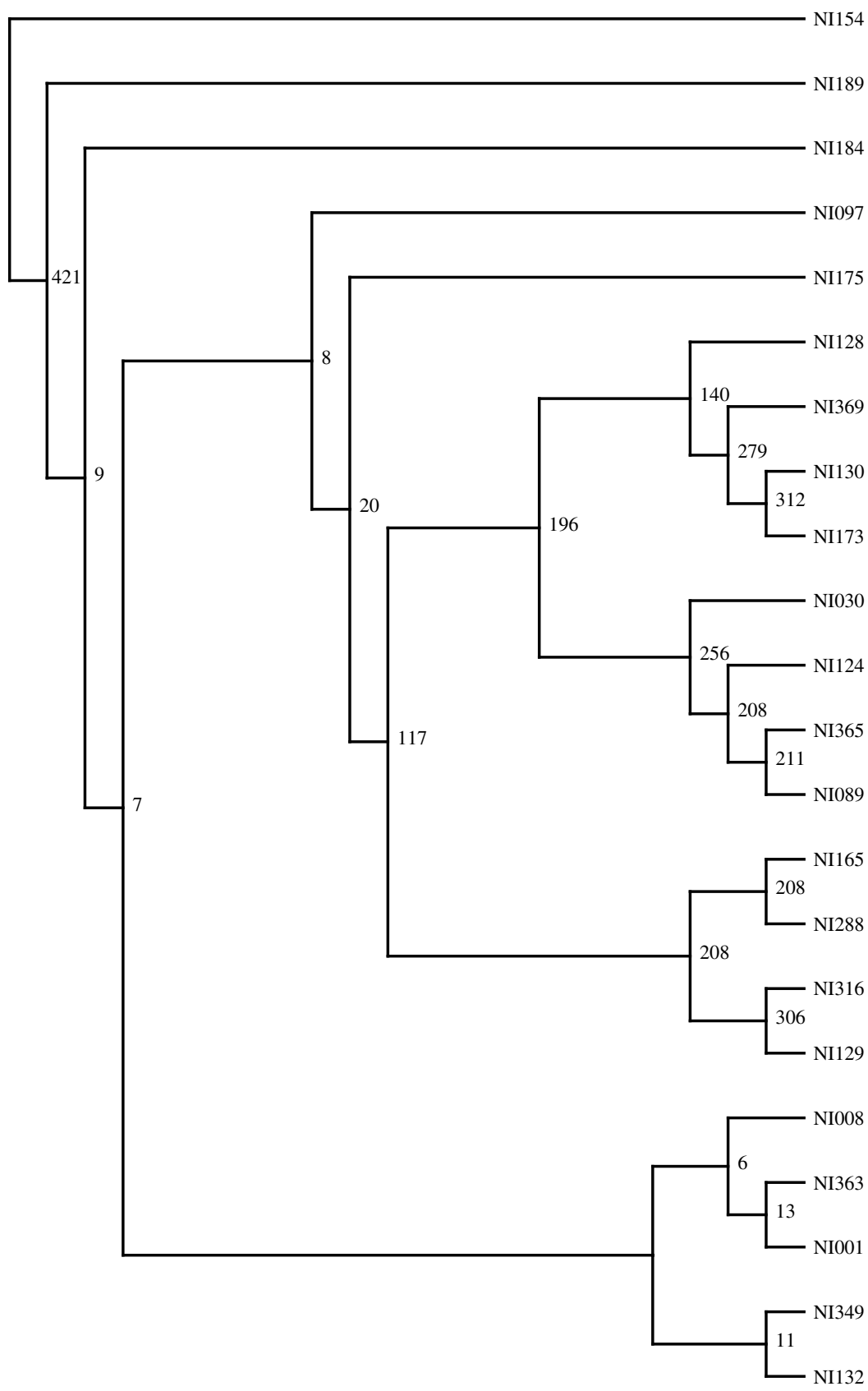

Fig. 4. Dendrogram of 22 accessions constructed using an UPGMA group analysis method based on Nei's (1987) genetic distance from allozymes data by Phylip program.

observations are in accordance with the criteria used by peasants to classify cultivars of $C$. mannii that is exclusively based on seed size.

The morphological variation in C. mannii from Côte d'Ivoire seemed to be uncorrelated to the cultivation regions. Two hypotheses could be suggested to explain such a result: the occurrence of an important seed flow or the similarity of the evolutionary history among the collecting zones. According to Montes-Hernandez and Eguiarte (2002) human activities significantly buffer plant geographic genetic variability.

\subsection{Allozymes variability}

The intra-accessions allozyme polymorphism indices estimated for $C$. mannii, were low compared to those reported by Hamrick and Godt (1997) for allogamous insect-pollinated species ( $\left.P=34 \% ; A=2.67 ; H_{\mathrm{e}}=0.205\right)$. These estimates were also 
lower than those published for others cucurbitaceous. Indeed, Montes-Hernandez and Eguiarte (2002) reported mean values of 96\%, 2.08 and 0.407, respectively for $P, A$, and $H_{\mathrm{e}}$ in Cucurbita argyrosperma Huber. ssp. argyrosperma and $C$. moschata Duch. Estimates obtained by Decker-Walters et al. (1990) in Cucurbita pepo L. were 19\%, 2.24 and 0.068 , respectively for $P, A$, and $H_{\mathrm{e}}$. Akimoto et al. (1999) estimated the mean value of $H_{\mathrm{e}}$ to 0.225 for an androdioecious cucurbit (Schizopepon bryoniaefolius Maxim.). On the other hand, estimates on C. mannii were similar to these reported by Decker-Walters et al. (1990) for Cucurbita maxima $\left(P=11.5 \% ; A=1.43 ; H_{\mathrm{e}}=0.039\right)$. A low level of intra-specific genetic variability based on allozyme data was also found in the genus Citrullus (Zamir et al., 1984; Biles et al., 1989), allowing Levi et al. (2001) to conclude that this genus had a narrow genetic basis. The level of genetic variability observed in C. mannii suggested the same conclusion. The analysed plants probably derived from a single ancestral parent, which has undergone morphological diversification driven by farmers' selection pressure, resulting in the three cultivars. Similar results have been published for two cultigroups of common bean (Fofana, 1999). Considering the low genetic variability observed in our C. mannii collection, one can assume that allozyme markers were not powerful enough to capture the genetic basis of the morphological variation, probably due to complex and multigenic inheritance of fruit and seed traits in cucurbits (Walters et al., 2001; Brown and Myers, 2002; Guner and Wehner, 2004).

The low allelic richness observed in the accessions studied could be attributed to founder effects, a higher and steady selfing rate, assortative mating (homogamy), or selection favouring homozygote individuals. However, the reproductive biology of indigenous cucurbit avoiding selfing makes the two later hypotheses (homogamy and homozygotes selection) improbable. Investigations reported for others cucurbits, showed that species of this family have predominantly an outcrossing mating system (Montes-Hernandez and Eguiarte, 2002). C. mannii is a monoceous (plant bearing separated staminate and pistilate flowers) insect-pollinated species. Thus this species is bound to experiment insect-mediated crosspollination which promotes random mating, buffering homogamy and homozygotes selection (Wright, 1951). This argument was supported by the fact that generally, the observed genotype frequencies were not significantly different from $\mathrm{H}-\mathrm{W}$ expectations. The most likely cause of the low allelic richness in C. mannii was the founder effects (bottleneck), due to farmers' seeds selection approaches. Indeed, in the collecting sites, seeds generally small in number, are usually taken from the last stock of the previous harvest, or obtained from neighbouring farmers or local markets, resulting to the genetic variability depletion (Nei et al., 1975).

Estimates of the genetic structure and gene flow parameters indicated that $C$. mannii maintained a high level of its allozyme variability within accessions. Likewise the intra-cultivar genetic diversity was higher $\left(H_{\mathrm{S}}=0.104\right)$ than its intercultivar component $\left(D_{\mathrm{ST}}=0.009\right)$. Accordingly, the among-accessions gene differentiation coefficient was low. The relatively high level of the within accessions and cultivars genetic diversity component compared to the genetic variation among accessions and cultivars was also in accordance with the mating system of $C$. mannii, coupled with farmers' seed management approaches.

On average, $F_{\mathrm{IS}}$ showed a significant deficiency of heterozygosity $\left(F_{\mathrm{IS}}>0\right)$ for all accessions. The proportion of the total genetic diversity found among accessions was high compared to that reported by Hamrick (1989) for the animal-pollinated species $\left(F_{\mathrm{ST}}=0.187\right)$, but similar to cross-pollinated plant $\left(F_{\mathrm{ST}}=0.234\right)$. The low genetic differentiation between accessions $\left(F_{S T}=0.298\right)$ confirmed the important rate of gene exchange between accessions revealed from Nei's gene diversity indices analysis. The degree of genetic differentiation observed between the cultivars was considerably low. It is suggested that the cultivars were recently established by human activities. Nei genetic distances between the three cultivars were also low (0.079-0.147), indicating that cultivars were similar enough to belong to the same genetic group.

In our study, trends of variation were not similar with the application of the two markers: morphology and allozymes. Djè et al. (1998) found similar results for sorghum landraces of northwestern Morocco. During the selection process, farmers and breeders favour phenotypic diversity, in order to meet adaptation to diverse cropping systems and consumer's requirements. From examination of the relationship between electrophoretic and morphological variation in wild Plantago species, Wolff (1991) attributed in part the difference observed to the effect of natural selection favouring differently morphological traits in different environments. For crop landraces, the observed differentiations are enhanced by artificial selection by farmers on some agronomic traits. Molecular markers (allozymes) that are less influenced by environmental do not reveal such variations (Kimura, 1979).

\section{Conclusion and implications for genetic resources collecting}

As the high loss of global biodiversity continues, devoting efforts to the conservation of genetic resources, particularly for indigenous crops are widely recommended. To achieve this objective, a better knowledge of the genetic diversity of the target crop is a prerequisite. Such analyses allow the identification of most valuable genotypes, populations, or accessions on the basis of the allelic richness. Morphological markers have been coupled to allozymes in order to study this diversity for one of the most widely consumed indigenous cucurbit in Sub-Saharan Africa: C. mannii.

From the present investigation, it was concluded that the indigenous oleaginous cucurbit $C$. mannii displayed a wide range of diversity for most of the morphological traits studied. The traits related to seed shape and size were the most cultivar distinctive. Consequently, seed morphological traits could be used for cultivar identification during collecting missions.

Isozyme electrophoresis data indicated a relatively high within accessions and cultivars genetic richness, compared to the among accessions and cultivars genetic variation. Such results suggested that for the genetic resources collecting, effort must be directed towards the number of seeds to be sampled, rather than the number of accessions. However, the low number of 
analysed loci and individuals suggest that analysis of additional accessions is required before a definitive conclusion can be performed.

\section{Acknowledgements}

This research was financed by the Direction General de la Cooperation au Développement (DGCD, Brussels, Belgium) and supervised by the Comité Universitaire pour le Developpement (CUD, Brussels, Belgium).

\section{References}

Achigan Dako, G.E., Fanou, F., Kouke, A., Avohou, A., Vodouhe, R.S., Ahanchede, A., 2006. Evaluation agronomique de trois especes de Egusi (Cucurbitaceae) utilisées dans l'alimentation au Bénin et élaboration d'un modèle de prédiction du rendement. Biotechnol. Agron. Soc. Environ. 10, $121-129$.

Achu, M.B., Fokou, E., Tchigang, C., Fotso, M., Tchouanguep, F.M., 2005. Nutritive value of some Cucurbitaceae oilseeds from different regions in Cameroon. Afr. J. Biotechnol. 4, 1329-1334.

Akimoto, J., Fukuhara, T., Kikuzawa, K., 1999. Sex ratios and genetic variation in a functionally androdioecious species, Schizopepon bryoniaefolius (Cucurbitaceae). Am. J. Bot. 86, 880-886.

Badifu, G.I.O., 1993. Food potentials of some unconventional oilseeds grown in Nigeria - a brief review. Plant Foods Hum. Nutr. 43, $211-224$.

Ban, D., Goreta, S., Borosic, J., 2006. Plant spacing and cultivar affect melon growth and yield components. Sci. Hortic. 109, $238-243$.

Biles, C.L., Martyn, R.D., Wilson, H.D., 1989. Isozymes and general proteins from various watermelon cultivars and tissue types. HortScience 24, 810-812.

Brown, A.H.D., Briggs, J.D., 1991. Sampling strategies for genetic variation in ex situ collections of endangered plant species. In: Falk, D.A., Holsinger, K.E (Eds.), Genetics and Conservation of Rare Plants. Oxford University Press, Oxford, UK, pp. 99-119.

Brown, R.N., Myers, J.R., 2002. A genetic map of squash (Cucurbita sp.) with randomly amplified polymorphic DNA markers and morphological markers. J. Am. Soc. Hortic. Sci. 127, 568-575.

Chapman, C.G.D., 1989. Collection strategies for the wild relatives of field crops. In: Brown, A.H.D., Frankel, O.H., Marshall, D.R., Williams, J.T. (Eds.), The Use of Plant Genetic Resources. Cambridge University Press, Cambridge, USA, pp. 263-279.

Crow, J.F., Aoki, K., 1984. Group selection for a polygenic behavioral trait: estimating the degree of population subdivision. Proc. Natl. Acad. Sci. U.S.A. 81, 6073-6077.

Dagnelie, P., 1986. Analyse statistique à plusieurs variables. Les presses Agronomiques de Gembloux, Gembloux (Belgique).

Das, M., Das, S.K., Suthar, S.H., 2002. Composition of seed and characteristics of oil from karingda [Citrullus lanatus (Thumb) Mansf]. Int. J. Food Sci. Technol. 37, 893-896.

Decker-Walters, S.D., Walters, T.W., Posluszny, U., Kevan, P.G., 1990. Genealogy and gene flow among annual domesticated species of Cucurbita. Can. J. Bot. 68, 782-789.

Dey, S.S., Singh, A.K., Chandel, D., Behera, T.K., 2006. Genetic diversity of bitter gourd (Momordica charantia L.) genotypes revealed by RAPD markers and agronomic traits. Sci. Hortic. 109, 21-28.

Djè, Y., Ater, M., Lefèbvre, C., Vekemans, X., 1998. Patterns of morphological and allozyme variation in sorghum landraces of Northwestern Morocco. Genet. Resour. Crop Evol. 45, 541-548.

Egunjobi, J.K., Adebisi, A.A., 2004. In: Grubben, G.J.H., Denton, O.A.(Eds.), Cucumeropsis mannii Naudin. [Internet] Record from Protabase. PROTA(Plant Resources of Tropical Africa/Ressources végétales de l'Afrique tropicale), Wageningen, Netherlands Available from: <http://database.prota.org/search.htm>.

Enujiugha, V.N., Ayodele-Oni, O., 2003. Evaluation of nutrients and some anti-nutrients in lesser-known, underutilized oilseeds. Int. J. Food Sci. Technol. 38, 525-528.

Erskine, W., Muehlbauer, F.J., 1991. Allozyme and morphological variability, outcrossing rate and core collection formation in lentil germplasm. Theor. Appl. Genet. 83, 119-125.

Felsentein, J., 1993. Phylip (Phylogeny Inference Package). Department of Genetics, Seattle (USA).

Ferriol, M., Pico, B., de Cordova, P.F., Nuez, F., 2004. Molecular diversity of a germplasm collection of squash (Cucurbita moschata) determined by SRAP and AFLP markers. Crop Sci. 44, 653-664.

Fofana, B., 1999. Etude de l'organisation de la diversité génétique de phaseolus lunatus L. par l'utilisation de marqueurs ADN nucléaires et chloroplastique. Unité de phytotechnie des régions intertropicales (Unité de biologie végétale). Faculté universitaire des sciences agronomiques de Gembloux (Belgique), Gembloux, p. 182.

Given, D.R., 1987. What the conservationist requires of ex situ collections. In: Branwell, D., Hamann, O., Heywood, V., Synge, H. (Eds.), Botanic Gardens and the World Conservation Strategy. Academic Press, London, pp. 103-116.

Guner, N., Wehner, T.C., 2004. The genes of watermelon. HortScience 39, 1175-1182.

Gusmini, G., 2003. Watermelon (Citrullus lanatus) Breeding Handbook. NC State University, Raleigh.

Hamrick, J.L., 1989. Isozymes and the analysis of genetic structure in plant populations. In: Soltis, D.E., Soltis, P.S. (Eds.), Advances in Plant Sciences Series. Dioscorides Press, Portland, Oregon, USA, pp. 87-105.

Hamrick, J.L., Godt, M.J.W., 1997. Allozyme diversity in cultivated crops. Crop Sci. 37, 26-30.

Kimura, M., 1979. Model of effectively neutral mutations in which selective constraint is incorporated. Proc. Natl. Acad. Sci. U.S.A. 76, 3440-3444.

Kjellqvist, E., 1975. The regional plan for collection, conservation and evaluation of genetic resources. In: Frankel, O.H., Hawkes, J.G. (Eds.), Crop Genetic Resources for Today and Tomorrow. Cambridge University Press, Cambridge, UK.

Knerr, L.D., Staub, J.E., Holder, D.J., May, B.P., 1989. Genetic diversity in Cucumis sativus L. assessed by variation at 18 allozyme coding loci. Theor. Appl. Genet. $78,119-128$.

Levi, A., Thomas, C.E., Keinath, P.A., Wehner, T.C., 2001. Genetic diversity among watermelon (Citrullus lanatus and Citrullus colocynthis) accessions. Genet. Resour. Crop Evol. 48, 559-566.

Loukou, A.L., Gnakri, D., Djè, Y., Kippré, A.V., Malice, M., Baudoin, J.P., Zoro Bi, I.A., 2007. Macronutrient composition of three cucurbit species cultivated for seed consumption in Côte d'Ivoire. Afr. J. Biotechnol. 6, 529-533.

Maggs-Kölling, G.L., Madsen, S., Christiansen, J.L., 2000. A phenetic analysis of morphological variation in Citrullus lanatus in Namibia. Genet. Resour. Crop Evol. 47, 385-393.

Marr, K.L., Xia, Y.-M., Bhattarai, N.K., 2007. Allozymic, morphological, phenological, linguistic, plant use, and nutritional data of Benincasa hispida (Cucurbitaceae). Econ. Bot. 61, 44-59.

Minitab, 1998. Minitab Statistical Package for Windows. Minitab Inc., Sales (USA)

Montes-Hernandez, S., Eguiarte, L.E., 2002. Genetic structure and indirect estimates of gene flow in three taxa of Cucurbita (Cucurbitaceae) in western Mexico. Am. J. Bot. 89, 1156-1163.

Morimoto, Y., Maundu, P., Fujimaki, H., Morishima, H., 2005. Diversity of landraces of the white-flowered gourd (Lagenaria siceraria) and its wild relatives in Kenya: fruit and seed morphology. Genet. Resour. Crop Evol. 52, 737-747.

Nei, M., 1987. Molecular Evolutionary Genetics. Columbia University Press, New York, USA.

Nei, M., Maruyama, T., Chakraborty, R., 1975. The bottleneck effect and genetic variability in populations. Evolution 29, 1-10.

Nerson, H., 2002. Relationship between plant density and fruit and seed production in muskmelon. J. Am. Soc. Hortic. Sci. 127, 855-859. 
Nerson, H., 2005. Effect of fruit shape and plant density on seed yield and quality of squash. Sci. Hortic. 105, $293-304$.

Osuji, O.J., Okoli, E.B., Heslop-Harisson, P.J.S., 2006. Cytology and molecular cytogenetics of Cucumeropsis mannii Naudin: implications for breeding and germplasm characterization. Int. J. Botany 2 (2), 187-192.

Paris, H.S., 2001. Characterization of Cucurbita pepo collection at the newe ya'ar research center, Israël. Plant Genet. Resour. Newsl. 126, 41-45.

Rasul, M.G., Hiramatsu, M., Okubo, H., 2007. Genetic relatedness (diversity) and cultivar identification by randomly amplified polymorphic DNA (RAPD) markers in teasle gourd (Momordica dioica Roxb.). Sci. Hortic. 111, 271-279.

Raymond, M., Rousset, F., 1995. Genepop (version 1.2): population genetics software for exact tests and ecumenicism. J. Hered. 86, 248-249.

Smith, S.E., Doss, A.A., Warburton, M., 1991. Morphological and agronomic variation in North African and Arabian alfalfas. Crop Sci. 31, 1159-1163.

Statistica, 1995. Statistica for Windows. StatSoft Inc., Tulsa.

Staub, J.E., Serquen, F.C., McCreight, J.D., 1997. Genetic diversity in cucumber (Cucumis sativus L.): III. an evaluation of Indian germplasm. Genet. Resour. Crop Evol. 44, 315-326.

Vekemans, X., Lefèbvre, C., 1997. On the evolution of heavy-metal tolerant populations in Armeria maritima: evidence from allozyme variation and reproductive barriers. J. Evol. Biol. 10, 175-191.

Walters, S.A., Shetty, N.V., Wehner, T.C., 2001. Segregation and linkage of several genes in cucumber. J. Am. Soc. Hortic. Sci. 126, 442-450.

Weir, B.S., Cockerham, C.C., 1984. Estimating F-statistics for the analysis of population structure. Evolution 38 (6), 1358-1370.

Wendel, J.F., Weeden, N.F., 1989. Visualization and interpretation of plant isozymes. In: Soltis, D.E., Soltis, P.S. (Eds.), Isozymes in Plant Biology. Dioscorides Press, Oregon, Portland, USA, pp. 5-44.

Wolff, K., 1991. Analysis of allozyme variability in tree Plantago species and a comparison to morphological variability. Theor. Appl. Genet. 81, 119-126.

Wright, S., 1951. The genetical structure of populations. Ann. Eugen. 15, 323-354.

Zamir, D., Navot, N., Rudich, J., 1984. Enzyme polymorphism in Citrullus lanatus and C. colocynthis in Israel and Sinai. Plant Syst. Evol. 146, 137-163.

Zoro Bi, I., Koffi, K.K., Djè, Y., 2003. Caractérisation botanique et agronomique de trois espèces de cucurbites consommées en sauces en Afrique de l'Ouest: Citrullus sp., Cucumeropsis mannii Naudin et Lagenaria siceraria (Molina) Standl. Biotechnol. Agron. Soc. Environ. 7, $189-199$.

Zoro Bi, I., Koffi, K.K., Djè, Y., Malice, M., Baudoin, J.P., Baus, E., 2005. Biodiversity of cucurbits consumed as sauce thickener in Côte d'Ivoire: a capital resource for the economic prosperity of rural women. In: Segers, H., Desmet, P. (Eds.), Tropical Biodiversity: Science, Data, Conservation. Global Biodiversity Information Facility (GBIF), Brussels (Belgium), pp. 158-167.

Zoro Bi, I., Koffi, K.K., Djè, Y., Malice, M., Baudoin, J.P., 2006. Indigenous cucurbits of Côte d'Ivoire: a review of their genetic resources. Sci. Nat. 3, 1-9.

Zoro Bi, I., Maquet, A., Baudoin, J.-P., 1999. Genetic control of isozymes in the gene pool Phaseolus lunatus L. Biotechnol. Agron. Soc. Environ. 13 , 10-27. 